\title{
VT-2249
}

FOR PARTICIPANTS ONLY

6 March 2002

ENGLISH ONLY

ECLAC

Economic Commission for Latin America and the Caribbean

World Bank

Seminar on Globalization

Santiago, Chile, 6-8 March 2002

\section{STRENGTHENING THE GLOBAL TRADE ARCHITECTURE FOR DEVELOPMENT}

\author{
Bernard Hoekman
}

This document was prepared by Bernard Hoekman, The World Bank and CEPR. The views expressed in this document, which has been reproduced without formal editing, are those of the author and do not necessarily reflect the views of the Organization. 



\title{
Strengthening the Global Trade Architecture for Development
}

\author{
Bernard Hoekman* \\ The World Bank and CEPR
}

January 2002

\begin{abstract}
Despite recurring rounds of trade liberalization under GATT/WTO auspices, complemented by unilateral reforms, many developing countries ha ve not been able to integrate into the world economy. This paper argues that from the perspective of the poorest countries, a multi-pronged strategy is required to strengthen the global trading system and that much of the agenda must be addressed outside the WTO. The most important contribution the WTO can make from a development perspective is to improve market access conditions--for goods and services-and ensure that trade rules are useful to developing countries. Enhancing trade capacity requires concerted action outside the WTO ('aid for trade') as well as unilateral actions by both industrialized and developing countries to reduce anti trade biases.
\end{abstract}

Keywords: WTO, economic development, multilateral trade negotiations, market access, technical assistance, capacity building

JEL codes: F13, F14

* Correspondence: Bhoekman@worldbank.org. The views expressed in this paper are personal and should not be attributed to the World Bank, its affiliated organizations, or the members of its Board of Executive Directors or the countries they represent. I am grateful to two referees, Ataman Aksoy, Jagdish Bhagwati, Richard Blackhurst, John Cuddy, Uri Dadush, Mike Finger, Carsten Fink, Will Martin, Keith Maskus, Aaditya Mattoo, Anne McGuirk, Patrick Messerlin, Constantine Michalopoulos, Marcelo Olarreaga, Susan Prowse, Richard Newfarmer, Sarath Rajapatirana, T.N. Srinivasan, Edith Wilson, John S. Wilson and Alan Winters for helpful comments, suggestions and discussions. The arguments in this paper draw in part on the results of a collaborative trade research and capacity-building project that has been supported financially by the UK Department for International Development, the Ministry of Development Cooperation of the Netherlands, Société Générale de Surveillance, and the World Bank. 


\section{Strengthening the Global Trade Archivecture for Development}

After the entry into force of the agreement establishing the World Trade Organization (WTO), it became clear that numerous governments, enterprises and nongovernmental organizations (NGOs) in developing countries were disappointed with the outcome of the Uruguay Round, both in terms of market access payoffs and the burden of implementing certain WTO agreements. More generally, an increasing number of observers have come to the view that efforts to negotiate disciplines on domestic regulatory policies in the WTO may divert attention away from critical development-related priorities or could result in inferior outcomes for low-income countries. ${ }^{1}$ In the run-up to the 1999 WTO ministerial meeting in Seattle, such concerns were reflected in calls for the launch of a 'Development Round' of negotiations. Similar calls were made in the run-up to the 2001 Ministerial Conference in Doha (e.g., World Bank, 2001c). The "Doha Development Agenda" that emerged from the fourth WTO ministerial clearly reflects the recognition of the need to put developing country concerns at the center of the WTO. Numerous provisions of the Doha Ministerial Declaration deal with developing country concerns, as does the Decision on Implementation-Related Issues and Concerns and the Declaration on the TRIPS Agreement and Public Health. The Declaration itself refers to development repeatedly and mentions commitments for technical assistance in over a dozen instances.

Although the negotiating agenda and work program that emerged from Doha illustrates the increased importance of developing countries in the trading system, achieving a pro-development outcome remains a major challenge. In part this is due to

\footnotetext{
${ }^{1}$ See, for example, Bhagwati (2000b), Rodrik (2001), Wang and Winters (2000), Hertel, Hoekman and Martin (2001), and the April 2000 issue of The World Economy. The Harvard Global Trade Negotiations
} 
the absence of strong support by OECD manufacturing industries for the agenda, reflecting the fact that market access barriers many industries are already quite low as a result of past zero-for-zero tariff reductions and the spread of free trade arrangements. Consequently, sector-specific interests seeking to maintain high rates of protection-in particular the textile industry in Canada and the US and the agricultural lobbies in the EU and Japan-did not confront much in the way of domestic countervailing forces. Moreover, the new issues on which the EU in particular sought to launch negotiations (environment, investment, competition, trade facilitation and transparency in government procurement) are regarded with great suspicion by many developing countries. Finally, many of these countries are not enthusiastic about engaging in further liberalization of access to their markets given institutional and trade capacity weaknesses.

This paper discusses how the global trade architecture might be made more supportive of development. ${ }^{2}$ Three major arguments are made, all of which can be seen as preconditions for greater coherence in international and national policymaking, improving the governance of the trading system, and, ultimately, 'managing globalization' (Helleiner, 2000). First, WTO members should give priority to a 'traditional' market access agenda that focuses on all products-goods and serviceswithout exception, that is, includes agriculture and labor-intensive manufactures such as apparel. Second, greater attention should focus on ensuring that WTO rules support development, and are seen to be doing so by stakeholders. This is a vital element of enhancing the development relevance of the WTO, and is likely to imply a need to limit

website http://www.cid.harvard.edu/cidtrade and www.worldbank.org/trade list numerous papers on the WTO agenda.

${ }^{2}$ This issue is also addressed in World Bank (2001c), Bhagwati (2000a), Oyejide (2000), Rodrik (2002) and Hoekman and Kostecki (2001). 
the ambit of the WTO. Third, market access and development 'friendly' WTO rules must be complemented by supply-side initiatives to address national trade capacity constraints and improve the investment climate in developing countries. This is arguably the most important dimension of strengthening the international trade architecture. It requires a substantial expansion of 'aid for trade'. As illustrated by Table 1, there are potentially many issues on the trade capacity agenda, and many organizations and bodies other than the WTO that have both the competence and the ability to provide support to low-income countries. Examples are specialized agencies such as the BIS, ISO, ITC, WCO, FAO etc., North-South regional agreements, and intemational financial institutions. ${ }^{3}$ The WTO does not have a large role to play in dealing with supply-side and institutional constraints confronting lowincome economies as these cannot be addressed through negotiations. Concerted multilateral efforts outside the WTO are needed to mobilize additional financial and technical assistance ('aid for trade'), channeled through development institutions, specialized bodies and the private sector.

In addition, unilateral actions by industrialized countries are needed to improve the 'terms of trade' of low-income economies - through duty-free and nontariff barrier free access to markets and elimination of aspects of investment, competition and related policy regimes that are detrimental to developing countries.

\footnotetext{
${ }^{3}$ The extent to which regional integration agreements include mechanisms to channel financial and other support to member countries varies of course. The assumption in Table 1 is that the focus is on agreements such as those the EU has concluded with partner countries (e.g., Euro-Mediterranean agreements).
} 
Table 1: Elements of the Global Trade Architecture for Development

\begin{tabular}{|l|c|c|c|c|c|}
\hline \multirow{2}{*}{} & \multicolumn{3}{|c|}{ Multilateral cooperation } & \multicolumn{2}{c|}{$\begin{array}{c}\text { Unilateral } \\
\text { actions }\end{array}$} \\
\cline { 2 - 6 } & WTO & $\begin{array}{c}\text { North-South } \\
\text { RIAs }\end{array}$ & $\begin{array}{c}\text { Specialized } \\
\text { bodies }\end{array}$ & DC & IC \\
\hline Market access & $\mathrm{A}$ & $\mathrm{A}$ & $\mathrm{S}$ & $\mathrm{A}$ & $\mathrm{A}, \mathrm{S}$ \\
\hline Rule making & & & & & \\
\hline Trade-related policies & $\mathrm{A}$ & $\mathrm{A}$ & $\mathrm{S}$ & $\mathrm{A}$ & $\mathrm{A}, \mathrm{S}$ \\
\hline Non-trade policies & & $\mathrm{A}$ & $\mathrm{A}, \mathrm{S}$ & $\mathrm{A}$ & $\mathrm{A}, \mathrm{S}$ \\
\hline Supply-side initiatives & & & & & \\
\hline Trade capacity development & & $\mathrm{S}$ & $\mathrm{S}$ & & $\mathrm{S}$ \\
\hline Institutional reform/strengthening: & & & & & \\
\hline Customs & & $\mathrm{S}$ & $\mathrm{A}, \mathrm{S}$ & $\mathrm{A}$ & $\mathrm{S}$ \\
\hline Tax administration & & $\mathrm{S}$ & $\mathrm{A}, \mathrm{S}$ & $\mathrm{A}$ & $\mathrm{S}$ \\
\hline Standards, certification & & $\mathrm{S}$ & $\mathrm{A}, \mathrm{S}$ & $\mathrm{A}$ & $\mathrm{S}$ \\
\hline Intellectual property & & $\mathrm{S}$ & $\mathrm{A}, \mathrm{S}$ & $\mathrm{A}$ & $\mathrm{S}$ \\
\hline Enforcement of agreements & $\mathrm{A}$ & $\mathrm{A}$ & $\mathrm{S}$ & $\mathrm{A}$ & $\mathrm{A}, \mathrm{S}$ \\
\hline Services: & & & & & \\
\hline Infrastructure upgrading & & $\mathrm{S}$ & $\mathrm{A}, \mathrm{S}$ & $\mathrm{A}$ & $\mathrm{S}$ \\
\hline Regulatory development & & $\mathrm{S}$ & $\mathrm{A}, \mathrm{S}$ & $\mathrm{A}$ & $\mathrm{S}$ \\
\hline Design of econormic policies & & $\mathrm{S}$ & $\mathrm{S}$ & $\mathrm{A}$ & $\mathrm{A}$ \\
\hline Social policy; redistribution & & $\mathrm{S}$ & $\mathrm{S}$ & $\mathrm{A}$ & $\mathrm{A}$ \\
\hline Notes: RIA: region
\end{tabular}

Notes: RIA: regional integration agreement; $\mathrm{A}$ - issue is a responsibility of a government or in the mandate of an international organization; $\mathrm{S}$ - support can be (is) provided by relevant entity to developing countries; DC: developing countries; IC: industrialized countries.

The paper is structured as follows. The first two sections focus on the WTO.

Section 1 discusses market access; Section 2 addresses rule making, implementation and enforcement. Section 3 turns to the complementary 'aid for trade' agenda, arguing that expanded multilateral cooperation outside the WTO to strengthen supply capacity and unilateral initiatives by industrialized nations to assist low-income economies are critical elements of improving the trade architecture. Section 4 briefly discusses the role of regional agreements. Section 5 concludes. 


\section{The WTO: Market Access}

Most-favored-nation tariff rates of developed countries are less than 5 percent on average. Indeed, much trade is now duty-free as a result of zero ratings, preferences and free trade agreements. However, tariffs for some commodities are over 100 percent. Such tariff peaks - rates above 15 percent-are often concentrated in products that are of interest to developing countries. In 1999, in the US alone, imports originating in least developed countries (LDCs) generated tariff revenue of $\$ 487$ million, equal to $11.6 \%$ of the value of their exports to the US, and $15.7 \%$ of dutiable imports (US Department of Commerce, 1999). ${ }^{4}$ Although the LDCs are by definition among the poorest countries in the world, in absolute terms most of the poor live in non-LDCs such as China, Egypt and India. From a poverty alleviation perspective, it is therefore vital that marker access improves for oll developing countries. This will require reciprocity; unilateral liberalization in the $\mathrm{OECD}$ is not politically feasible-governments must be able to point to 'compensating' reductions in developing country trade barriers.

Because average tariff barriers in developing countries are higher than in industrialized nations, much of the potential welfare gains from reducing trade barriers will arise from own liberalization. ${ }^{6}$ The large potential payoff from reciprocal tariff liberalization provides a strong rationale for developing countries to engage in traditional GATT-type tariff negotiations-greater efficiency in home markets and cheaper access to

\footnotetext{
${ }^{4}$ This calculation excludes Angola, $95 \%$ of whose exports are oil-related and not dutiable. The LDCs comprise 49 low-income countries, mostly in Africa.

5 This was illustrated in Doha by the resistance by Canada and the US against any increase in the textile quota growth rates agreed to in the Uruguay Round. Finger and Winters (2001) and Srinivasan (1998) discuss the role of reciprocity in the WTO.

${ }^{6}$ See Hertel and Martin (2000) and Bhagwati and Panagariya (2000).
} 
imports will be complemented by better access to export markets. ${ }^{7}$ This argument applies to LDCs as well. As noted by Winters (1999), a useful mnemonic in this connection is WYDIWYG: what you do is what you get. When it comes to trade policy, the payoffs to negotiations and liberalization are primarily a function of domestic action-the extent to which own protection is reduced. ${ }^{8}$

Two sectors that matter greatly for developing countries are textiles and agriculture. Although the WTO Agreement on Textiles and Clothing requires the abolition of all textile quotas by January 1, 2005, tariff barriers to trade in this sector remain high. High tariffs for agricultural commodities and extensive subsidization of agriculture in many OECD countries has a major detrimental effect on agricultural exporters such as Argentina and Brazil. Not surprisingly, these sectors were very high on the developing country agenda at the Doha ministerial.

In addition to labor-intensive manufacturing and agriculture, liberalization of services trade and investment is a major element of the market access agenda. Back of the envelope calculations by Winters (2001) suggest that the income gains that could accrue to developing country nationals from allowing an increase in temporary access by service suppliers equivalent to 5 percent of the OECD population are in the $\$ 300$ billion rangegreater than the gains from abolition of merchandise trade barriers (World Bank, 2001c). However, here again the greatest gains to developing countries would come from

\footnotetext{
7 There is a preponderance of evidence that there is a positive relationship between openness to trade and growth (e.g., Dollar and Kraay, 2001; World Bank, 2001b, Srinivasan and Bhagwati, 1999). Sceptics such as Rodrik (2001) argue that the strong association between trade (openness) and growth is not informative regarding the underlying policies and institutions that are required to support both. Most will agree that good governance and macro policies, effective safety nets, investment in health and education, and adequate infrastructure must complement trade liberalization (World Bank, 2001a).

${ }^{8}$ Fiscal constraints may imply that low-income countries need to maintain tariffs above the average prevailing in more advanced economies for revenue collection purposes. In such cases, countries should consider greatly reducing the dispersion in duty rates by moving towards a uniform tariff (Tarr, 2002).
} 
reforming their own policies—increasing the efficiency of service industries may generate welfare improvements that are a multiple of those associated with liberalization of goods trade. The reason is that in contrast to tariffs, services trade and investment restrictions do not generate revenue for the government. Instead, they tend to raise costs for users, imposing a 'tax' on the whole economy. ${ }^{9}$ Liberalization of services is more complex than negotiating down tariff barriers, as it involves movement of people, foreign direct investment (FDI) and regulatory reform. A careful evaluation of services trade policy requires analysis of the conditions of competition in a particular sector and the need for regulation to achieve efficiency and equity (Mattoo, 2001). As discussed below, 'trade for aid' is needed to assist in the design of reforms.

Market access has two additional important dimensions: reducing uncertainty by disciplining the use of contingent protection and minimizing the downside of RIAs. The threat of safeguards and related policies (especially antidumping) reduces the value of trade liberalization to exporters. Antidumping has become a frequently used instrument in both industria lized and developing countries. Indeed, Finger et al. (2000) document that developing countries such as India and Mexico have become major users. Disciplining the use of antidumping is therefore important from a systemic perspective. As discussed below, RIAs have a potential role to play in addressing the supply side and trade capacity constraints, if designed well. However, they also lead to discrimination and trade diversion. A major benefit of WTO-based nondiscriminatory reductions in trade barriers is to reduce the costs of RIAs for nonmembers (World Bank, 2000). Given the importance of the two issues for developing countries, the decision at the Doha

\footnotetext{
9 Konan (2001) and World Bank (2001c) simulate the potential gains from service sector reform. Stern (2002) surveys the literature.
} 
ministerial to launch negotiations on both subjects is beneficial from a development perspective. Of course, past experience suggests that moving WTO rules towards better policy in these areas will be difficult.

\section{WTO Rule Making, Implementation and Enforcement}

WTO negotiations on 'behind-the-border' policies have proven to be more complex than traditional market access talks because it is much more difficult to trade 'concessions'. The focus therefore tends to be on identification of specific rules that should be adopted by the WTO (Hoekman and Kostecki, 2001). Given disparities in economic power and resources, the focal point of discussions tends to be the status quo in high-income countries. This may be fully consistent with development priorities of low-income countries, but there is no presumption this will be the case.

Developing country worries regarding the rule-making dimensions of the WTO became increasingly prominent in the 1990s (Oyejide, 2000). Concerns centered on the costs associated with implementation of certain WTO agreements and the absence of adequate financial assistance; the failure of high-income countries to deliver promised 'special and differential' treatment to developing countries; and, more fundamentally, perceptions that some of the rules of the game constrain national efforts to increase economic growth.

Post-Uruguay Round research—in particular Finger and Schuler (2000) and Finger (2001) - revealed that the costs associated with complying with certain WTO disciplines-e.g., on customs valuation-can be significant. This is not so much because of the rules themselves, but because of the ancillary investments that are required to 
allow the rule to be applied. As mentioned, because WTO rules are often based on those prevailing in OECD countries, implementation costs are asymmetrically distributed. This does not necessarily imply that WTO rules are bad from a development perspectivemost rules reflect good policy ${ }^{10}$ - making them work in low-income countries may require wholesale reform and strengthening of a variety of institutions. Table 2 provides a 'birds-eye view' of the development economics and implementation dimensions of major WTO disciplines.

Table 2: Development Dimensions of Major WTO Rules and Disciplines

\begin{tabular}{|c|c|c|c|}
\hline Agreement on: & $\begin{array}{l}\text { Encourages } \\
\text { moves towards } \\
\text { good policy? }\end{array}$ & $\begin{array}{l}\text { Significant direct } \\
\text { implementation } \\
\text { costs? }\end{array}$ & $\begin{array}{l}\text { Significant corollary } \\
\text { imvestment required } \\
\text { (isndirect costs)? }\end{array}$ \\
\hline Transparency & Yes & $\mathrm{No}$ & No \\
\hline Tariff reductions & Yes & No & No \\
\hline Tariff binding & Yes & No & No \\
\hline Customs valuation & $?$ & Yes & $\overline{Y e s}$ \\
\hline Classification (HS) & Yes & $\overline{\text { Yes }}$ & No \\
\hline Production subsidies & $?$ & No & No \\
\hline Export subsidies & $?$ & $\overline{\text { No }}$ & No \\
\hline Quotas & $\overline{\text { Yes }}$ & No & No \\
\hline Balance of payments & No & No & No \\
\hline Antidumping & No & $\overline{Y e s}$ & No \\
\hline Countervail & No & Yes & No \\
\hline Emergency protection & $?$ & Yes & No \\
\hline GATS & Yes & No & Yes \\
\hline TRIPS & $?$ & $\overline{\text { Yes }}$ & Yes \\
\hline Technical barriers & Yes & Yes & Yes \\
\hline SPS measures & $\overline{\text { Yes }}$ & Yes & Yes \\
\hline Agriculture & $\overline{\text { Yes }}$ & No & No \\
\hline Import licensing & $\overrightarrow{\text { Yes }}$ & No & $\overline{\text { No }}$ \\
\hline Rules of origin & $\overline{\text { Yes }}$ & Yes & No \\
\hline State trading & $\overline{\text { Yes }}$ & No & No \\
\hline Regional integration & $\overline{\text { Yes }}$ & No & No \\
\hline Textiles \& clothing & Yes & Yes & $\overline{\text { No }}$ \\
\hline
\end{tabular}

Note: See Hoekman and Kostecki (2001) for a motivation of the normative assessments; McCulloch, Winters and Cirera (2001) for an analysis of the likely poverty impact of WTO rules.

\footnotetext{
${ }^{10}$ Exceptions are the antidumping agreement, which many economists agree makes no economic sense, and TRIPs - where many argue that the costs may outweigh the gains for low-income countries. See Maskus (2000) for a survey of the literature on TRIPs.
} 
From a development perspective, the resources required for implementation, if substantial, might be better used for alternative purposes (Finger and Schuler, 2000). This is an important point, one that has yet to be fully intermalized by many WTO members. An illustration of this is the Doha declaration's call for technical assistance to be provided for virtually every subject area to be negotiated/discussed. While this makes sense in terms of supporting participation by low-income nations, the presumption is that all these issues are national priorities. This is clearly not the case.

\subsection{Towards Greater Ownership: Participation and Transparency}

The Uruguay Round marked a change in the attitudes of many developing countries regarding the trading system. From being largely uninvolved and reactive, many became active participants in the negotiating process (Tussie and Lengyel, 2002). This did not prevent many countries from being confronted with what they came to regard as bad outcomes. Participation is not enough; to be effective it requires a clear understanding of national objectives and priorities, and how multilateral agreements can help achieve them. At the time of the Uruguay Round, there was only limited developing country experience in "new areas" such as intellectual property protection, product standards or service sector regulation. Indeed, many countries have yet to create intellectual property regimes that makes traditional knowledge or cultural products into a negotiable and defensible asset, or to identify alternative options to upgrade and enforce national product, health and safety standards. 
In many regulatory areas, the trial and error experience-the assessments of the reat world impacts of alternative policy options - that can inform the design of multilateral rules that support development does not exist (Finger, 2001). This lack of experience makes it difficult to establish lines of communication between policymakers and domestic constituents that have interests that can be pursued through multilateral talks-be it domestic reform or policy changes in partner countries to enhance market access. Industrialized country policymakers are generally well informed (lobbied) by domestic interest groups. Most developing countries have much weaker linkages with stakeholders, impeding their ability to build the political support needed for welfareimproving reforms.

Greater 'ownership' of the WTO requires that multilateral agreements be seen as helpful in order to atrain national objectives. Getting it right in a technocratic sense is not sufficient; there must be strong local support for what is (being) negotiated. As interests will differ and often will be inconsistent, mechanisms to allow the resulting distributional conflicts to be resolved in a transparent fashion must exist. This is not straightforward to achieve, given that trade policy is inherently a nontransparent redistributive policy instrument, and is often used for that reason. A vital element in promoting better policies is transparency and access to information. Much of the focus of attention in this regard has been on enhancing the transparency of WTO operations and improving access toand dissemination of -WTO databases, reports and information. While this is imporant - for example, better access to data underlying WTO trade policy reviews and public access to databases on tariff bindings would help think tanks, firms and NGOs 
engage in the domestic policy formation process (Francois, 2001) ${ }^{11}$-it is necessary that the required analysis is done by stakeholders. It is a truism that to reduce protection and resist protectionist pressures those that lose (pay) need to be aware of the costs of such policies if they are to defend their interests.

Even if the requisite analysis is undertaken and is reflected in domestic policy debates and the formulation of national positions, a precondition for defending these interests is effective representation in Geneva. Many low-income countries do not have a presence at the WTO, impeding active engagement in negotiations. Indeed, many have yet to become a member. Although options have been identified to expand representation in Geneva at relatively low cost-for example, Blackhurst, Lyakurwa and Oyejide (2000) propose transferring natiomal representatives from UN bodies to Geneva and more intense cooperation among members of regional integration arrangements-there is limited expertise available in most countries. A case can be made that funding should be made available to allow low-income countries to hire experts to assist governments to undertake the required analyses (Winters, 2001). Such advice and expertise needs to be available on a long-term basis to policymakers on a country-by-country basis. Given that there are dozens of countries requiring assistance (the LDC group alone already numbers 49), the needs in this area are significant. ${ }^{12}$

\footnotetext{
${ }^{11}$ Data on tariff bindings are currently not publicly available in a usable database format, preventing analysts from undertaking cross-country research. This is important because it impedes efforts to estimate the magnitude and incidence of costs of protection.

12 At the Doha ministerial meeting a decision was made by donors to establish the Agency for International Trade Information and Cooperation (AITIC) as an inter-governmental organization. Originally created in 1998 with Swiss funding, AITIC provides information, training, and personalized assistance services for delegations representing LDCs and a limited number of other developing and transition economies, including WTO members and countries in accession without missions in Geneva. This assistance is free of charge and funded by the donor community. See www.acici.org.
} 
Even if countries are ready and willing to engage in WTO negotiations, they may find it difficult to do so effectively. Traditionally, contentious issues on which deals must be struck are thrashed out in so-called Green room meetings, comprising the major OECD members and a small number of developing countries. At the Seattle ministerial meeting many developing countries that were excluded from critical Green room meetings felt that they were not being informed of developments or granted the opportunity to defend their views. In Doha, a 'Committee of the Whole' approach was followed, under which all interested WTO members were invited to participate in plenary meetings, as well as in six working groups dealing with the major outstanding issues whose chair persons reported regularly the commirtee of the whole (heads of delegations). This 'hub-andspoke' system worked reasonably well and was a major improvement over Seattle. However, this approach is not possible on a day-to-day basis, i.e., does not resolve the Geneva representation issue.

Proposals have been made periodically to replace the informal Green room process with a formal mechanism that allows all countries to be represented. Possibilities that have been suggested include an Executive Committee with membership based on shares in world trade (Schott and Buurman, 1994) and a formal, non-decision-taking Consultative Board with rotating membership that would operate in instances where Green Rom meetings cannot accommodate all WTO members wishing to participate in a discussion on an issue (Blackhurst, 2001). The objective of the Board would be to put forward (non-binding) recommendations to the entire membership. To date, no progress in this direction has proven possible in the WTO. However, as membership continues to 
expand - China and Chinese Taipei joined in Doha-it will become increasingly difficult to operate on the basis of consensus.

\subsection{The Regulatory Agenda and Issue Linkage}

A lesson from the Uruguay Round is that multilateral efforts to harmonize regulatory policies should be scrutinized carefully. Another lesson is that the WTO is not necessarily the right focal point for harmonization efforts. There are many organizations and bodies that seek to determine good practices and establish international norms for regulatory policies. Examples are international product standards set by the International Organization for Standardization, phytosanitary norms established by the Codex Alimentarius Commission, financial standards created under auspices of the Bank for International Settlements and good practices in customs clearance defined by the World Customs Organization. In all these cases the norms concerned are not arrived at through a negotiating process where market access is made conditional on the adoption of specific norm. Instead, cooperation is driven by the self-interest of countries, and implementation is gradual, depending on national circumstances and capacity, assisted by the relevant international institutions as well as bilateral donors. There is generally no binding dispute settlement mechanism or threat of sanction for non-implementation. The latter factor is of course a major reason why sectoral interest groups propose regulatory standards for inclusion in the WTO. However, there is a great danger in overloading the institution and reducing its legitimacy and support by using it as an enforcement agency for voluntary, 'good practice' norms developed by other technical and specialized bodies. 
One reason regulatory issues are put on the agenda is that this allows cross-issue linkages in WTO negotiations. While this increases the potential gains from negotiation (see Hoekman and Kostecki 2001 for a guide to the literature), a necessary condition for this is that the implications of alternative deals are understood, and that trade is an appropriate instrument of enforcement. When it comes to 'new' issues on which developing countries have little experience, it may be difficult to determine whether a 'grand bargain' will have a net positive social payoff. This is a major reason why developing country negotiators have often been risk averse in GATT/WTO negotiations and sought to avoid issue linkage. ${ }^{13}$ At the same time, lack of information and good analysis can also resuln in missed opportunities to use linkage to achieve better policies at home or in trading parnmers-ignorance discourages actions that may be beneficial. Determining the expected cost-benefit ratio of proposed agreements is therefore important. So is assessing whether it makes sense to use trade as an enforcement device-something that depends on how 'trade-related' an issue is.

Two policy areas where cooperation is best pursued outside the WTO are environmental and social regulation. Developing countries need to be supported in creating the property and social rights that will ensure that national resources are allocated in an equitable and efficient manner. The WTO is not the place to set domestic standards in these areas, nor is trade the optimal enforcement instrument to enforce norms. Trade sanctions can easily worsen social or environmental outcomes (e.g., by forcing workers in targeted countries into informal or illegal activities). Account should also be taken of the obvious danger that protectionist interests will capture the process.

\footnotetext{
${ }^{13}$ See, e.g., the statement by 99 third world NGO representatives and intellectuals against linkage between social and environmental issues and market access in the WTO (TWIN-SAL, 2001).
} 
Positive incentives are needed—carrots, not sticks. Direct support and assistance of the type provided by specialized bodies with the requisite expertise such as the ILO and multilateral development agencies can most efficiently and directly improve outcomes. Examples are efforts to improve the quality of, and access to, primary education for poor children in order to reduce child labor exploitation, e.g., via programs to subsidize the purchase of school supplies, provide transportation, and reduce the costs of schooling (Maskus, 1997). In the case of environmental policies-which clearly can give rise to serious global commons issues-the appropriate approach is again cooperation outside the WTO ${ }^{14}$ As far as the WTO is concerned, the primary need is to clarify the relationship between WTO rules and multilateral environmental agreements (Rollo and Winters, 2000), eliminate subsides that have large negative environmental spillovers (e.g., to the coal or fishing industry), and ensure that unilateral actions motivated by environmental objectives-such as eco-labeling-are consistent with the WTO.

The Doha ministerial launched negotiations on the first two issues, as well as the reduction of barriers to trade in environmental goods and services. Eco-labeling is to continue to be part of the Committee on Trade and Environment's work program, with a decision whether to launch negotiations to be taken at the fifth ministerial. Ministers reaffirmed the decision taken at the 1996 Singapore ministerial that labor standards issues should be addressed in the ILO. Thus, to date the approach that is being taken in the WTO towards these two areas is largely consistent with the principles summarized above. Other regulatory policy areas where WTO negotiations have been proposed for some time include industrial, investment, competition, trade facilitation and public

\footnotetext{
14 There is a large literature that provides strong support for these conclusions $\rightarrow$ see, e.g., Anderson and Blackhurst (1992) and Bhagwati and Srinivasan (1996).
} 
procurement policies. In Doha, it was agreed that negotiations on the last four of these socalled Singapore issues "will take place after the Fifth Session of the Ministerial Conference on the basis of a decision to be taken, by explicit consensus, at that Session on the modalities of negotiations." 15 These policy areas are more trade-related than labor or the environment. For example, $\mathrm{OECD}$ antitrust exemptions for anti-competitive behavior by national firms on export markets (e.g., shipping conferences, export cartels) ${ }^{16}$ and investment incentives that aim to prevent firms from relocating are both detrimental to the trade prospects of developing countries. Thus, in principle there may be a justification for negotiating rules.

In the area of industrial policy, the WTO already imposes a number of disciplines, including on subsidies and local content policies. These have implications for the design of export processing zones and other export incentive schemes, and governments need to ensure that WTO rules in these areas do not restrict their ability to pursue good policies. As far as the four Singapore issues are concerned, the basic question is whether and how multilateral disciplines could help promote the adoption of good policy in each area. While space constraints prevent discussion of the substantive issues that arise, ${ }^{17}$ a key factor determining the development-relevance of agreements will be the extent to which policies of trading partners that are harmful to poor countries are addressed-e.g., OECD antitrust exemptions for export cartels and investment incentives. The less this is the case,

\footnotetext{
15 Here the issue will revolve around whether the aim should be to negotiate multilateral or plurilateral agreements. As argued above, countries are well-advised to pursue the multilateral route and use the consensus-based operation of the WTO to ensure that the rules are in their interest. If the plurilateral route is taken, it is critical that agreements apply on an MFN basis.

${ }^{16}$ See Fink, Mattoo and Neagu (2001), Francois and Wooton (2001) and World Bank (2001c).

${ }^{17}$ For a dis cussion of multilateral rules for the so-called Singapore issues, see Hoekman and Kostecki (2001) and the references cited there. For general approaches to such issues, see Rollo and Winters (2000) and Maskus (1999).
} 
the weaker the rationale for using the WTO as opposed to other non-binding fora as a vehicle for multilateral cooperation. Many question whether multilateral disciplines on issues such as investment or competition will address development priorities. Simply participating in discussions and negotiations on such issues requires the use of scarce administrative resources, and therefore has a potentially high opportunity cost (Wang and Winters, 2000). If the primary reason for considering to negotiate on such policies is for purposes of issue linkage, efforts may be better directed at other areas-starting with market access (see below).

\subsection{Implementation of Agreements}

Even if WTO agreements have strong support in developing countries, implementation may be costly. Doing more to assess the impacts of agreements ex ante, including a costing out of investment requirements, would help avoid difficulties ex post. The challenge here is to allow for development concerns to be taken into account in instances where resource constraints prevent effective implementation of WTO agreements that were deemed at the time of negotiation to be beneficial. ${ }^{18}$ What is required is a type of safeguard mechanism that allows implementation problems to be considered in the context of a nation's overall development strategy.

The approach that is currently pursued in the WTO with respect to implementation problems is primarily agreement-specific, generally involving requests for extension of transition periods in relevant WTO bodies. This approach does not allow for an

\footnotetext{
18 It should be emphasized that the focus of what follows is on agreements that were deemed to be desirable cannot be implemented as envisaged due to a lack of resources or absence of complementary reforms and institutional strengthening. Agreements that can be implemented 'by decree' e.g., changes in tariffs or reductions in subsidies - would not eligible for the approach described. There the need is to
} 
assessment of needs in the context of the overall development strategy of the countries concerned and does nothing to place trade issues in the context of the country assistance strategies of international financial institutions and bilateral donor assistance agencies.

One option could be to make transition periods a function of national circumstances. This is already done to some extent- the WTO makes a distinction between least developed and other developing countries and grants the former longer transition periods and greater 'special and differential' treatment. This is rather arbitrary in that it ignores differences across countries. A better approach would to link implementation of resourceintensive agreements to the provision of development assistance, and adopt an arbitration approach to implementation disputes that involve low-income countries. Such arbitration could be based con an independent 'implementation assessment' at the request of governments who have been unable to meet WTO norms. This would involve a determination of what is required to implement the agreement(s) in a way that makes sense from an economic perspective (including a costing out of necessary ancillary reforms and investments), the time frame that would be required given sequencing considerations and institutional capacity, and an assessment of the adequacy of the financial assistance that has been offered by donors (Finger, 1998 has suggested that such assistance should be made mandatory, and a number of developing countries have made proposals to that effect). ${ }^{19}$ The assessment, which would need to be transparent and

\footnotetext{
ensure $a b$ initio that commitments are welfare improving.

${ }^{19}$ Such assessments could be informed by national development frameworks such as the Poverty Reduction Strategy Paper (PRSP) in the case of low-income economies, as these establish development priorities on a country-by-country basis (see www.worldbank.org for a description of the PRSP process). In the case of LDCs, diagnostic reports prepared under auspices of the Integrated Framework (IF) for trade related technical assistance could also be part of the implementation assessment process. The IF is a joint venture of six international agencies (IMF, ITC, UNCTAD, UNDP, World Bank and WTO), donors and LDCs. The IF supports efforts to ensure that trade policy, trade-related technical assistance, and capacity-building needs are articulated in a broader development context.
} 
objective, might be undertaken by a panel of development experts in consultation with national economic policymakers, reporting to the WTO Committee on Trade and Development.

A mechanism of this kind could help foster greater policy 'coherence' by providing a vehicle to discuss how WTO disciplines requiring the investment of scarce resources can be implemented consistently with a country's development strategy. The objective would not be to allow for open-ended opt-outs and to avoid situations where implementation periods are repeatedly pushed back following requests for extension. The approach would generate information on the constraints that prevail, and the adequacy of the assistance that has been provided or offered. By providing a forum for the development and trade communities to interact on implementation issues, it could help both developing and donor countries improve internal policy coherence.

\subsection{Enforcement of agreements}

Issues relating to the cost of satisfying WTO rules and non- fulfillment of assistance commitments by trading partners are only one part of the implementation agenda. Another concerns enforcement of rights and obligations. Low income countries may have difficulty doing so through the WTO dispute settlement system. ${ }^{20}$ Political realities-e.g., threats of cross-issue linkages and retaliation outside the WTO-may constrain the ability (willingness) of governments to assist national firms defend their WTO rights. Poor countries may also find it more difficult to determine when trading partners use WTO-illegal policies to harm their interests.

${ }^{20}$ For an in-depth discussion, see Hoekman and Mavroidis (2000). 
Various suggestions have been made to deal with this potential problem. One is to reduce the burden for individual countries to take action by establishing an independent Special Prosecutor or Advocate. This entity could be granted the mandate to identify potential WTO violations on behalf of developing countries. Such outsourcing of 'discovery' could help leverage the activities of the Advisory Centre for WTO Lawwhich started to provide legal counseling services to developing countries in late $2001^{21}$ - by addressing both the resource constraints and the incentive problems (fear of cross-issue linkage) that may impede developing country governments from pursuing cases. Although limited to a transparency function, this can lead to significant moral pressure to bring measures into conformity with the WTO. ${ }^{22}$

\section{Actions Ontside}

Although market access and pro-development WTO rules are important from a development perspective, the primary determinant of a country's economic performance is its ow policy. A liberal trade policy - one that implies relatively low and uniform effective protection and no quantitative restrictions-complemented by institutions to facilitate trade and attain social objectives is a necessary condition for success in harnessing trade for development. Designing and sustaining supporting policies and institutions are not trivial tasks. Actions by development institutions and industrialized countries to assist developing countries augment their trade capacity and improve their investment climate is critical in strengthening the global trade architecture.

\footnotetext{
${ }^{21}$ It does so at below-market rates, based on donor provided resources (see www.acwl.ch).
} 


\subsection{Multilateral Cooperation: 'Aid for Trade'}

A precondition for domestic 'ownership' of WTO agreements is that there are constituencies that have an incentive to see specific reforms and commitments implemented and enforced. Support for country-specific efforts to identify reform priorities and infrastructure needs (both software and hardware) is an important dimension of this, as is identification of policy options and their distributional and growth impact, and, critically, mobilization of finance to address the priority bottlenecks to trade and employment expansion. Trade-related challenges confronting most developing countries include meeting export market product standards, protecting intellectual property, regulating service industries, improving trade logistics and customs clearance, and, upgrading transport, communications and other basic infrastructure services (Staples, 2002; World Bank, 2001a,c). All of these policy areas are important dimensions of the overall investment climate and determinants of trade capacity; which (if any) are priorities will depend on individual count ries. What follows discusses a number of possible priority areas.

\section{Bridging the Global Product Standards Divide}

Many low-income countries are not adequately equipped to adopt and enforce product standard requirements. Testing and certification requirements can also be serious obstacles for developing country exporters. Recent examples include Ugandan fish and South Asian shrimp, as well as new EU standards for aflatoxin that could reduce export revenue for African countries by more than $\$ 600$ million (Otsuki, Wilson and Sewadeh,

\footnotetext{
${ }^{22}$ Historically, this 'Dracula principle' (Bhagwati 1988) has been an important factor in inducing WTO members to abide by the rules of the game.
} 
2001). Developing countries face a series of challenges: they need to reform and upgrade standards setting regimes, establish efficient testing, certification, and laboratory accreditation mechanisms to conform with sanitary and phytosanitary (SPS) norms and technical product standards, and defend their interests in international standards-setting bodies that design global norms (Henson, Preibisch and Masakure, 2001). The latter has become particularly important following the presumption of the WTO that members should apply existing international standards. Modernizing infrastructure and building capacity to meet global regulatory requirements and standards can have large payoffs in terms of expanding trade opportunities. The same is true of reducing transactions costs associased with redundant testing and certification requirements, and efforts to ensure that intemational standards set by specialized bodies are appropriate for developing countries. All such actions require resources. An initiative to bring together major development institutions, specialized standards setting bodies and bilateral donors to assist developing countries address such issues would help improve competitiveness and expand trade opportunities (Wilson, 2001).

\section{Intellectual Property Rights and Development}

The WTO agreement on TRIPs has attracted much critical attention. Whatever its faults, the agreement provides a great deal of latitude in terms of how countries implement it (Watal, 2002). A variety of policies can be pursued to reduce the magnitude of the income transfer from South to North that will be associated with implementation of TRIPs. Examples include facilitating the absorption and diffusion of know-how, vigorous enforcement of competition law, and direct regulation (Correa, 2000; Maskus, 2000). 
Low-income countries need to identify intellectual property that could and should be protected, thereby creating commercial assets whose value can be defended and augmented through the negotiation of international rules (Finger and Nogues, 2001). Designing an intellectual property regime that is relevant for the situation and characteristics of a developing country is not straightforward. Simply copying the regime that is in place in an OECD country often will not do. Funding to identify assets that could benefit from protection and possible methods to do so is therefore required, focusing in particular on sectors in which traditional knowledge is a factor of production: music, crafts and design, community-based tourism, ethno-botanicals (Penna and Visser, 2002).

\section{Service Sector Liberalization and Regulatory Reform}

The scope for gains from services liberalization is very large-given high barriers to competition in many sectors and countries, recent studies suggest that real income gains of 5 to 10 percent of GDP are attainable (Stern, 2002, Konan, 2001). However, such liberalization must be accompanied by effective regulation to ensure that market failures are addressed and that social objectives-such as universal service-are met. For example, the absence of pro-competitive regulatory policies may substantially reduce the

social payoff to privatization if it results in rent transfers to the new private owners of the firms. The need for effective regulation of financial services was highlighted by the emerging market financial crises in the late 1990s. The establishment of regulatory disciplines and institutions may involve substantial startup and running costs, as well as sophisticated skills. For example, a bare-bones telecom regulatory authority in Dominica 
would cost $\$ 2$ million each year, or 5\% percent of the total budget (Mattoo, 2001). To some extent such costs can be recovered through fees or reduced via regional cooperation-but external assistance can help ensure that adequate regulation is in place.

\section{Trade Facilitation}

Trade facilitation comprises the simplification and harmonization of international procedures affecting trade flows. Customs-related transaction costs-red tape-can represent up to 10 percent of a shipment's value in some countries (Staples, 2002). Costs are compounded if there is corruption and delay. More efficient procedures, electronic data exchange and minimizing redundancy can provide important benefits. Good practices in this area have been identified and agreed multilaterally under auspices of the World Customs Organization (WCO)-see Messerlin and Zarrouk (2000). The Doha ministerial declaration included a commitment to launch negotiations on this topic with modalities to be determined at the 2003 ministerial conference.

Many developing countries will be hard pressed to attain the good practices laid out in the WCO convention, given weak institutions, lack of modem communications and information systems, inadequately trained staff, etc. Developing countries are still struggling to implement the WTO customs valuation agreement, and they have doubts about the value of accepting additional mandatory obligations on trade facilitation given weak institutional structures, lack of modern communications and information systems, inadequately trained staff, and so forth. Even Canada, a developed country with ample resources, took five years to complete implementation of the valuation agreement (Staples, 2002). Many countries will only be able to attain the good practices that are 
enumerated in the WCO conventions gradually. Significant technical and financial assistance is needed for training and institutional strengthening, including in ancillary areas such as tax administration. A similar conclusion applies to areas such as competition law and government procurement.

\subsection{Unilateral Actions by High-Income Countries}

The foregoing examples of 'aid for trade' delivered outside the WTO context could usefully be complemented by unilateral initiatives by industrialized countries. The decision by the EU in 2001 to grant LDCs duty- and quota-free access for all products is an example. Full elimination of market access barriers can help boost investment incentives and expand trade-related employment. Emulation by all OECD countries of the EU initiative would therefore be beneficial to these countries-potentially increasing LDC exports by over 10 percent. $^{23}$ As LDCs account for only $0.5 \%$ of world trade, offering these countries duty free access will have only a very limited effect on total imports into $\mathrm{OECD}$ nations-suggesting that adjustment pressures will be small. Of course, preferential access for LDCs will have detrimental trade diversion effects for other low-income countries, although the very small share of the world market that is held by LDCs suggests such effects will be small in relation to total non-LDC exports. It is also the case that because LDCs have no market power in negotiating down foreign trade barriers-where tariff peaks can be over 100 percent-they cannot play the WTO reciprocity game. ${ }^{24}$ Duty-free access for LDCs can be complemented by exemption from

\footnotetext{
23 Ianchovichina, Mattoo and Olarreaga (2000); UNCTAD (2001).

${ }^{24}$ The best policy would be to remove all barriers on products in which developing countries have a comparative advantage on a nondiscriminatory basis. As mentioned previously, this is unlikely to be feasible on a unilateral basis, given that a number of low-income countries are significant exporters-it will
} 
the threat of antidumping and safeguard actions, and efforts to ensure that non-tariff measures do not impede market access. Examples are rules of origin and product standards-which, if too stringent, may effectively nullify the duty-free access opportunity.

There are also areas beyond trade policy narrowly defined where unilateral actions can be taken to assist developing country exporters and consumers. One example is in the enforcement of competition law by OECD countries. Given the absence of effective competition agencies in most low-income countries, OECD competition authorities could transmit information collected in the course of investigations that reveal anticompetitive behavior by furms in their jurisdiction that has a detrimental effect on one or more developing countries. Removal of antitrust exemptions for export cartels and maritime liner conferences would also benefit developing countries, especially if actively enforced by home country competition agencies. Consideration could be given to transferring fines imposed for transgressions affecting developing country markets to these countries.

\section{Regional Integration Agreements}

Many countries increasingly pursue trade policy and related reforms in the context of RIAs. Such initiatives can be regarded as an example of international cooperation through which governments seek to adopt better policies and strengthen trade-related institutions. Whether RIAs will help members integrate into the world economy and benefit from increased trade depends very much on how they are designed. Classic free trade agreements that are limited to trade in goods are least likely to be beneficial to 
developing countries, unless concluded with major industrialized partners such as the EU or US. In general, the risks of welfare reducing outcomes are reduced if the implementation of RIAs is accompanied by a reduction in external barriers to trade.

As argued in World Bank (2000), North-South RIAs can be particularly beneficial to developing countries if these are associated with additional development assistance that aims at improving trade capacity and related institutions, have very few (ideally no) exemptions in terms of product coverage, and include trade in services. That said, one of the problems with RIAs is that they can easily be detrimental to excluded countries, giving rise to adverse terms of trade effects as well as so-called investment diversion. This amplifies the importance of member countries using RIAs as part of a global integration strategy and minimizing the extent of discrimination against non-members. A major function of the WTO in this regard is to provide a mechanism to ensure that is the case - through periodic rounds of liberalization of trade in both goods and services.

\section{Conclusion}

This paper asks what appears to be a simple question: how to strengthen the global trade architecture from a development perspective? The basic message that emerges is that efforts need to go far beyond the WTO. Much of the agenda cannot be addressed by the WTO. Indeed, a case can be made for scaling the WTO back to focus primarily on a market access agenda.

In concluding, it is useful to start by summarizing some of the negative aspects of the current architecture for developing countries: 
- The prevailing pattern of protection in the world today is biased against the poor in that barriers are highest on goods produced by poor people-agriculture and unskilled labor-intensive manufactures and services (World Bank, 2001c);

- Interest groups are increasingly seeking to use trade as a tool to enforce rules for non-trade policies;

- There is a participation (capacity) constraint - both at home and in the WTOthat impedes developing countries from ensuring that WTO agenda items and mukilateral rules reflect their interests;

- Given that negotiation and implementation of agreements can be costly, there is a danger of 'resource diversion' away from development priorities;

- There is an excessive reliance on litigation to enforce agreements.

From a development perspective, the best thing the WTO can do is to focus primarily on trade policies where multilateral disciplines would have the highest development payoff. A large body of research suggests that this involves market access liberalization in both industrialized and developing countries. Much remains to be done, not only in reducing tariffs, but in dealing with nontariff measures such as antidumping, restrictive product standards and rules of origin, and in liberalizing trade in services (World Bank, 2001c). Given that the Doha ministerial launched negotiations on barriers to trade in manufactures, as well as agriculture, services and antidumping, the outcome was a good one.

However, Doha also confirmed once again how difficult is the task confronting developing countries when it comes to market access. The two topics that were most controversial at the ministerial conference_- deal breakers' — were demands by 
developing countries (led by India) that the US and Canada increase textile quotas in the 2002-4 period, and the insistence of many countries that the EU accept the eventual elimination of agricultural export subsidies as a negotiating objective. High profile issues such as TRIPS and public health proved to be easier to resolve.

This raises the question whether the engine of reciprocity has lost its effectiveness in the WTO. Clearly it is less powerful than in the past given that intra-OECD barriers are very low, developing country barriers have come down significantly, and, in the case of the US, industries can invoke Section 301 to put pressure on foreign governments to open their markets. Thus, it is perhaps not surprising that there were few industry groups lobbying for liberalization in Doha. The absence of domestic countervailing forces in the Quad that oppose textile and agricultural lobbies' pressure for continued protection implies that developing countries must take the lead. Given high barriers to trade in goods and services in developing countries, they have a lot to bring to the table in a mercantilist sense. Indeed, there should be more than enough to 'trade' in the market access areas. An implication is that negotiations on issues such as investment and competition may not be necessary in terms of making progress on market access and should be considered on their own merits. If in principle rules are deemed to be a priority or regarded as beneficial, moving towards an arbitration-cum-surveillance approach to enforce implementation of those agreements that require institutional strengthening and complementary investments could do much to reduce perceptions of downside risk on the part of low-income countries.

Solutions to the participation and implementation problems, many of which are interrelated, must involve a more coherent approach to multilateral cooperation in the trade 
area. Ensuring that WTO rules make sense requires understanding of the issues in developing countries, not just by government officials but by the private sector and civil society. Despite 5 years of studying trade and investment/competition linkages in working groups set up for that purpose, it was obvious that many low-income countries were fearful of the possible implications of launching negotiations in these areas. There is clearly a need to provide greater assistance to build capacity and undertake analysis in developing countries.

The Doha declaration contains numerous commitments on the part of WTO members to provide technical assis tance. In the areas of investment and competition this is to be provided in cooperation with "other relevant intergovernmental organizations ... and through appropriate regional and bilateral channels." In the areas of market access, govermment procurement and trade facilitation there is no such language, and, by implication it appears that these are areas where the WTO secretariat is expected to take the lead in providing assistance. In the case of environment, the declaration recognizes the importance of technical assistance, but makes no commitments.

The Doha approach of supplying technical assistance on an issue-by-issue basis, while understandable given the desire of high-income nations to launch negotiations, risks diverting both policy attention and aid away from the most urgent problems. Embedding technical assistance in a broader development framework would help ensure that it focuses on the priority needs that exist in a country and is consistent with its development strategy. The separate section in the Doha declaration on technical cooperation and capacity building provides some scope to move in this direction: Ministers "instruct the Secretariat, in coordination with other relevant agencies, to support domestic efforts for 
mainstreaming trade into national plans for economic development and strategies for poverty reduction" (para. 38). This offers an opportunity to launch a concerted effort to minimize the risk of resource diversion, and to ensure that the entities with a comparative advantage in an area are asked to take the lead (e.g., the WCO on trade facilitation). Organizing the delivery of technical assistance promised in Doha in a way that promotes development is a major challenge.

Action outside the WTO to address key institutional and trade infrastructure constraints in low-income developing economies (as opposed to enhancing understanding of WTO negotiating/work program issues) is the most important dimension of strengthening the global trade architecture. This has a number of dimensions. One is to accept that non-trade issues or policy areas that have at best a weak relationship with market access may be best dealt with in fora other than the WTO. Another is to pursue the 'complementary agenda' that revolves around upgrading the trade capacity of the poorest countries. This potentially spans a large number of areas. The development and growth prospects of countries and their ability to benefit from expanded trade opportunities depend on the quality of infrastructure and related services (ports, roads, telecoms), education, public health, the judicial system, etc., as well as a country's own trade and investment policies. All of these impact on the investment climate and are critical to the empowerment of people. Governments and stakeholders should take the lead in identifying priorities; greater 'aid for trade' could significantly improve their ability to deal with them.

Finally, unilateral actions by industrialized countries can do much to assist developing countries exploit trade opportunities. Duty- and quota-free access, and minimizing 
uncertainty as regards the conditions of market access are critical 'facilitating practices' that can reduce the disincentives to pursue reforms in low-income countries.

Summing up, many aspects of the trade agenda are development issues that may be best addressed in other fora through a process of cooperation and voluntary action as opposed to negotiation and binding dispute settlement. Suggestions to expand the agenda of the WTO must therefore be considered carefully. Whether the issue is important from a development perspective and whether it makes systemic sense to address it through negotiations in the WTO are questions that developing countries (and more broadly those concerned with development) need to answer for themselves. The Doha ministerial revealed that ramy countries had an answer. It also revealed that many did not. Greater technical and other assistance to help countries determine where their interests lie is therefore important. But most important from a development perspective is to use the WTO for what it was designed to do and in what it bas been extremely effective over many decades-the reciprocal removal of barriers to trade in goods and services. 


\section{References}

Anderson, K. and R. Blackhurst (eds.). 1993. The Greening of World Trade Issues (London: Harvester-Wheatsheaf).

Anderson, K., B. Dimaranan, J. Francois, T. Hertel, B. Hoekman and W. Martin. 2001. "The Cost of Rich (and Poor) Country Protection to Developing Countries," Journal of African Economies, forthcoming.

Bhagwati, J. 1988. Protectionism (Cambridge, Mass.: MIT Press).

Bhagwati, J. 2000a. The Wind of the Hundred Days: How Washington Mismanaged Globalization. Cambridge: MIT Press.

Bhagwati, J. 2000b. "After Seattle: Free Trade and the WTO," International Affairs, $77: 15-30$.

Bhagwati, J. and A. Panagariya. 2000. "Wanted: Jubilee 2010 Against Protectionism," Council on Foreign Relations, mimeo (http://www.columbia.edu/ jb38/).

Bhagwati, J. and T.N. Srinivasan. 1996. "Trade and the Environment: Does Environmental Diversity Detract From the Case for Free Trade?", in J. Bhagwati and R. Hudec (eds.), Harmonization and Fair Trade (Cambridge: MIT Press).

Blackhurst, R. 2001. "Reforming WTO Decision Making: Lessons from Singapore and Seattle," in K. Deutsch and B. Speyer (eds.), The WTO Millennium Round: Freer Trade in the Twenty-First Century, (London: Routledge).

Blackhurst, R., W. Lyakurwa and A. Oyejide. 2000. “Options for Improving Africa's Participation in the WTO," The World Economy, 23: 491-510.

Correa, C. 2000. "The Strengthening of IPRs in Developing Countries and Complimentary Legislation," mimeo (www.dfid.gov.uk).

Dollar, D. and A. Kraay (2001). 'Growth Is Good for the Poor,' World Bank Policy Research Working Paper No. 2587.

Finger, J.M. 2001. "Implementing the Uruguay Round Agreements: Problems for Developing Countries," Global Trade Policy (special issue of The World Economy), forthcoming.

Finger, J.M. and J. Nogues. 2000. "WTO Negotiations and the Domestic Politics of Protection and Reform," mimeo.

Finger, J. M. and P. Schuler. 2000. "Implementation of Uruguay Round Commitments: The Development Challenge" The World Economy, 23:511-26.

Finger, J.M. and L. A. Winters. 2002. "Reciprocity," in B. Hoekman, P. English and A. Mattoo (eds.), Development, Trade and the WTO: A Handbook, Washington: World Bank, forthcoming.

Finger, J.M., F. Ng, and S. Wangchuk. 2000. "Antidumping as Safeguard Policy,” World Bank, mimeo. 
Fink, C. A. Mattoo and I. Neagu. 2001. "Trade in International Maritime Services: How Much Does Policy Matter?," Policy Research Working Paper 2522, World Bank (www.worldbank.org/trade).

Francois, J. 2001. "Maximizing the Benefits of the TPRM for Developing Countries," in B. Hoekman and W. Martin (eds.), Developing Countries and the WTO: A ProActive Agenda. Oxford: Basil Blackwell.

Francois, J. and I. Wooton. 2001. "Trade in International Transport Services: The Role of Competition," Review of International Economics, 9:249-61.

Helleiner, G. 2000. "Markets, Politics, and Globalization: Can the Global Economy be Civilized?," $10^{\text {th }}$ Prebisch lecture, UNCTAD, mimeo (www.unctad.org).

Hertel, T. and W. Martin. 2000. "Liberalizing Agriculture and Manufactures in a Millennium Round: Implications for Developing Countries," The World Economy, 23:455-70.

Hertel, T. B. Hoekman and W. Martin. 2001. "Developing Countries and a New Round of WTO Negotiations," World Bank Research Observer, forthcoming.

Henson, S., K. Preibisch, O. Masakure. 2001. "Review of Developing Country Needs and Involvement in Intemational Standards-Setting Bodies" (www.dfid.gov.uk).

Hoekman. and M. Kostecki. 2001. The Political Economy of the World Trading System: The WTO and Beyond. Second Edition. Oxford: Oxford University Press.

Hoelman, B. and P.C. Mavroidis. 2000. "WTO Dispute Settlement, Transparency and Surveillance," The World Economy, 23: 527-42.

Ianchovichina, E. A. Mattoo and M. Olarreaga. 2001. "Unrestricted Market Access For Sub-Saharan Africa: How much is it worth and who pays?," Policy Research Working Paper 2595, World Bank (www.worldbank.org/trade).

Konan, D. 2001. "Simulating the Impact of Alternative Trade Reform Scenarios for Egypt and Tunisia," report prepared for the Council on Foreign Relations, mimeo.

Maskus, K. 1997. "Should Core Iabor Standards Be Imposed through International Trade Policy?", Policy Research Working Paper 1817 (www.worldbank.org/trade)

Maskus, K. 2000. Intellectual Property Rights in the Global Economy. Washington: Institute for International Economics.

Mattoo, A. 2001. "Liberalizing Trade in Services," World Bank, mimeo (www.worldbank.org/trade).

McCulloch, N., L. A. Winters and X. Cirera. 2001. Trade Liberalization and Poverty: A Handbook. London: CEPR.

Messerlin, P. and J. Zarrouk. 2000. "Trade Facilitation: Technical Regulations and Customs Procedures," World Economy, 23: 577-94.

Otsuki, T., J.S. Wilson, and M. Sewadeh. 2001. "A Race to the Top? Food Safety Standards and African Exports," Policy Research Paper 2563, World Bank. 
Oyejide, T. Ademola. 2000. "Interests and Options of Developing Countries and LDCs in a New Round of Multilateral Trade Negotiations," G-24 Discussion Paper No. 2. New York: United Nations (May).

Penna, F. and C. Visser. 2002. "Cultural Industries and Intellectual Property Rights," in B. Hoekman, P. English and A. Mattoo (eds.), Development, Trade and the WTO: A Handbook, Washington: World Bank, forthcoming.

Rajapatirana, S., C. Lusthaus and M. Adrien. 2000. "Review of the Integrated Framework for Technical Assistance for Trade Development of Least Developed Countries," World Bank, June 6, mimeo.

Rodrik, Dani. 2001. "The Global Governance of Trade as if Development Really Mattered," (www.cid.harvard.edu/cidtrade/issues/developmentpapers).

Rodrik, Dani. 2002. "Trade Policy Reform and Institutional Reform," in B. Hoekman, P. English and A. Mattoo (eds.), Development, Trade and the WTO: A Handbook, Washington: World Bank, forthcoming.

Rollo, J. and L.A. Winters, 2000, "Subsidiarity and Governance Challenges for the WTO," The World Economy, 23: 561-76.

Srinivasan, T.N. 1998. Developing Countries and the Multilateral Trading System. New York: Harper Collins.

Srinivasan, T.N. and J. Bhagwati. 1999. "Outward Orientation: Are the Revisionists Right?," Center Discussion Paper 806, Yale University.

Staples, B. 2002. "Trade Facilitation: Improving the Invisible Infrastructure," in B. Hoekman, P. English and A. Mattoo (eds.), Development, Trade and the WTO: A Handbook, Washington: World Bank, forthcoming.

Stern, R. 2002. "Quantifying Barriers to Trade in Services," in B. Hoekman, P. English and A. Mattoo (eds.), Development, Trade and the WTO: A Handbook, Washington: World Bank, forthcoming.

Tarr, D. 2002. "Arguments for and Against Uniform Tariffs," in B. Hoekman, P. English and A. Mattoo (eds.), Development, Trade and the WTO: A Handbook, Washington: World Bank, forthcoming.

Third World Intellectuals and NGO Statement Against Linkage (TWIN-SAL). 2001. downloadable from http://www.columa.edu/ jb38/.

Tussie, D. and M. Lengyel. 2002. "Developing Country Participation versus Influence," in B. Hoekman, P. English and A. Mattoo (eds.), Development, Trade and the WTO: A Handbook, Washington: World Bank, forthcoming.

UNCTAD. 2001. Duty and Quota Free Market Access for LDCs: An Analysis of Quad Initiatives. Geneva: UNCTAD.

United States Department of Commerce. 1999. US Merchandise Trade: Selected Highlights. Washington DC: US Government Printing Office. 
Wang, Z. K. and L.A. Winters. 2000. "Putting "Humpty" Together Again: Including Developing Countries in a Consensus for the WTO," London: Royal Institute for International Affairs.

Watal, J. 2002. "Implementing the TRIPs Agreement," in B. Hoekman, P. English and A. Mattoo (eds.), Development, Trade and the WTO: A Handbook, Washington:

World Bank, forthcoming.

Wilson, J. S. 2001. "Bridging the Standards Divide: Recommendations for Reform from a Development Perspective," World Bank, mimeo (www.worldbank.org/trade).

Winters, L.A. 1999. "Trade Policy as Development Policy," presented at the UNCTAD X High-level Round Table on Trade and Development (www.unctad.org).

Winters, L.A. 2001. "Harnessing Trade for Development," University of Sussex, mimeo.

World Bank. 2000. Trade Blocs. Policy Research Report. Washington DC: World Bank.

World Bank. 2001a. "Trade Policy," Poverty Reduction Strategy sourcebook (www.worldbank.org/poverty/strategies/chapters/).

World Bank. 2001b. Globalization, Growth and Poverty. Policy Research Report. Washington DC: World Bank, forthcoming.

World Bank 2001c. Global Economic Prospects and the Developing Countries: Making Trade Work for the World's Poor. Washington DC: World Bank. 


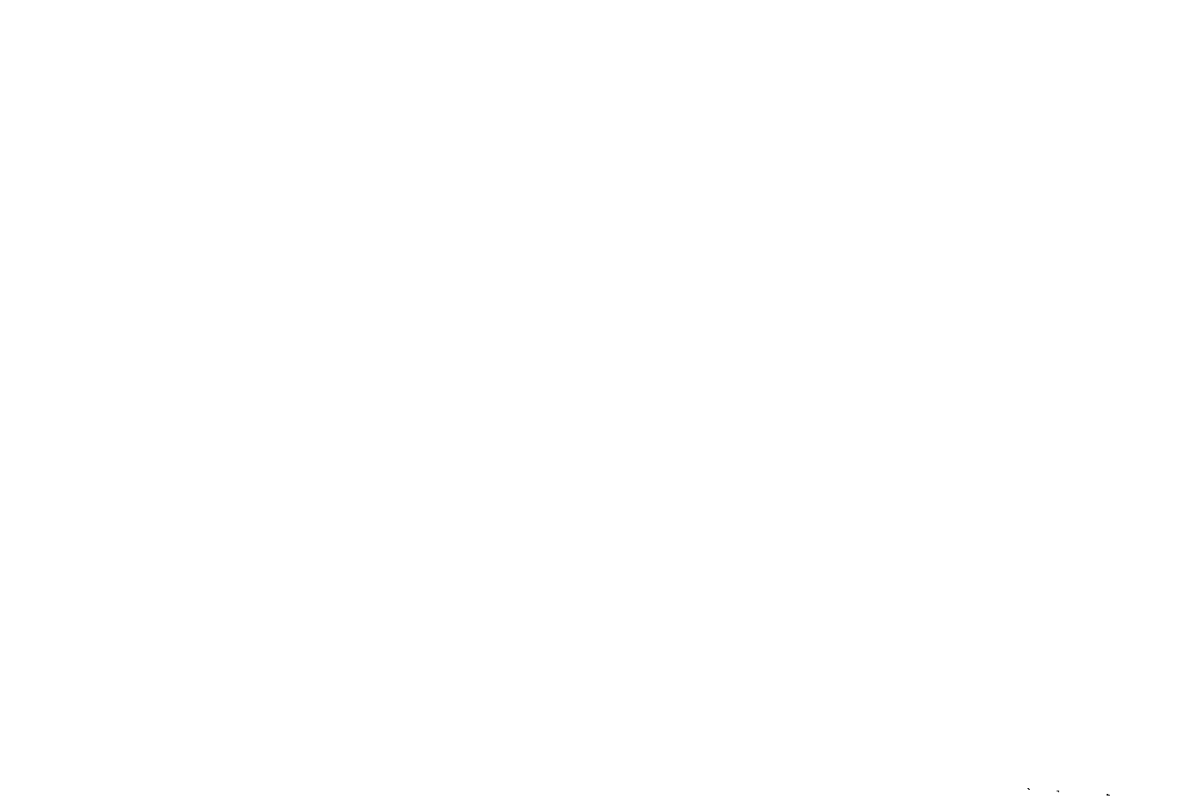



